\title{
Where is the Third $E$ in Controlling Coronavirus Disease-19 in Indonesia? A Mini Review
}

\author{
Paul Sirait ${ }^{1 *(1)}$, Fotarisman Zaluchu ${ }^{2}$ (D) \\ ${ }^{1}$ Department of Public Health, Institut Kesehatan Sumatera Utara, Medan, Indonesia; ${ }^{2}$ Department of Anthropology, Faculty of \\ Social Sciences and Politics, Universitas Sumatera Utara, Medan, Indonesia
}

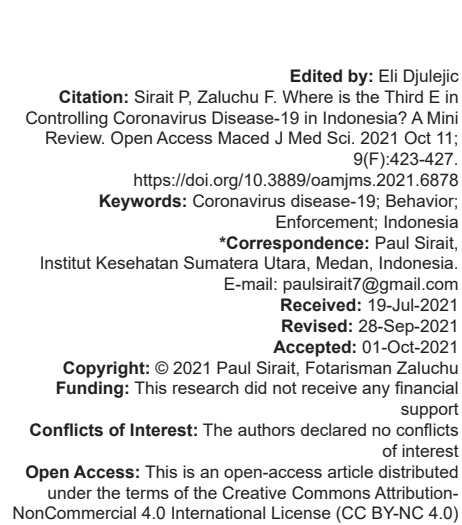

\section{Introduction}

At present, coronavirus disease (COVID- 19) is still a problem in the world today. The WHO reported that the number of COVID-19 cases in the world reached 188,655,968 confirmed cases. Meanwhile, global deaths have been reported to have reached 4,067,517 deaths [1]. In July 2021, Indonesia has become the new epicenter of COVID- 19 in the world. Within days, Indonesia reported more than 50,000 more daily cases, far more than any other country. In 4 consecutive days, the number of positive cases reported even reached 54,000 cases in 1 day [2], placing Indonesia with the highest case reports in Asia together with India [3] so that it became one of the countries in the WHO spotlight [4]. At the same time, the daily death rate is also more than 1000 people per day [2].

This condition is interesting to be discussed through this review. When many countries have taken various approaches, the condition of Indonesia needs to be a concern. Especially, when we discuss efforts to change people's behavior. Various approaches to behavior change have been reviewed, but more holistic integration is needed. This paper reviews the enforcement approach as an alternative in the future, which has previously been proven theoretically and its application to other public health problems.

\section{Context}

The Indonesian government has carried out mass vaccinations since January 2021. As a result, as of July 18, 2021, 41 million first doses have been carried out, and 16.2 million second doses have been completed [5]. Indeed, this figure is still far from the 208 million Indonesian population targeted to receive the vaccine. Moreover, at the same time, vaccinations are also carried out in the 12-17 years age group plus booster vaccinations for health workers.

Since the beginning of the pandemic, the Indonesian government has determined that the COVID-19 control policy cannot be pursued by carrying out mass restrictions which are often referred to as lockdowns. The government chooses a "limited" diction rather than stopping all community activities.

However, overtime, this policy resulted in serious negative impacts. The community then relaxed their activities. Many people in the community ignore 
the use of masks. Not only that, often social activities are carried out without maintaining distance and even creating crowds. Markets and community activities in many places are running as usual as if without COVID- 19. People are also used to making visits to public areas, tourist areas, and places to relax, which should not be done. As a result, the circulation of COVID-19 slowly crawled up and caused an explosion of cases in mid-July 2021.

The description of community activities can be seen from the pattern of community mobility before July, especially from May to June (Figure 1).

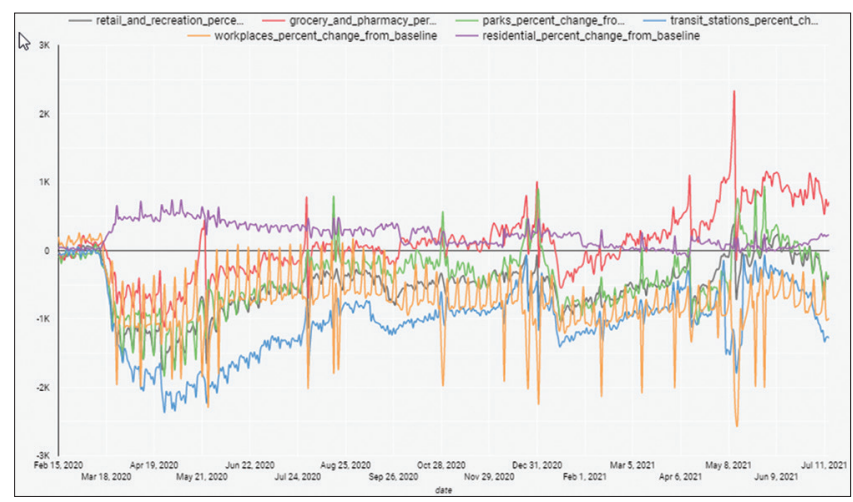

Figure 1: Indonesia Google Mobility Report. (Source: https:// datastudio.google.com/reporting/page, accessed July 18, 2021)

To respond to the exploding COVID-19 case, the Indonesian government immediately took action. In Java and Bali, emergency Pemberlakuan Pembatasan Kegiatan Masyarakat (PPKM) was carried out. All so-called non-essential activities are suspended. The emergency PPKM policy then expanded to 15 other areas outside Java-Bali. To prevent the situation from worsening, the government asked other countries to supply oxygen. Medical personnel worked hard to help patients because the queues of patients suddenly became long. Many patients can no longer be helped by the time they arrive at the hospital. Funeral records also rose dramatically. When cases explode, the use of technology, including tele-medicine, so that patients can be served even though they are self-isolating, is carried out as much as possible.

In the 2 weeks, since the implementation of the emergency PPKM, it appears that there has been a decline in population mobility (Figure 2 ) as recorded by Google Mobility. It turns out that the emergency PPKM

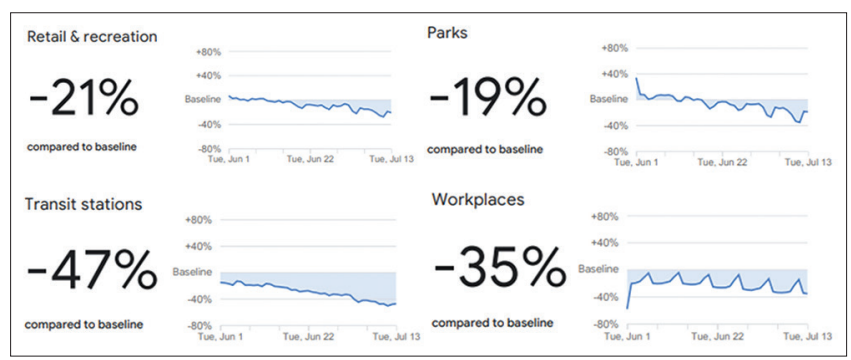

Figure 2: Decreasing in mobility in Indonesia during the past 10 weeks (source: https://www.google.com/covid19/mobility/ accessed July 17, 2021) action is a method that can stop mass mobility of the population, as is seen today.

But still, there is a big problem in citizen discipline which is far from ideal. If this continues to happen, where every time a case occurs, then mass activities are stopped, then overtime the healthcare system will collapse. It is even possible that the health sector may not revive again, even though the emergency response plan has been well prepared.

Hence, in the face of COVID-19, behavior change requires serious efforts. It must be acknowledged that to date, the core of disease control for COVID-19 has been control of humans, which carry the SARS-CoV-2 virus, or non-pharmaceutical interventions [6], [7].

\section{What is the Three Es?}

Humans have behavioral complexities. Behavior change approach requires a theoretical approach [8]. One of the concepts that have been formulated is to include discipline in behavior change [9].

The three Es' concept was conveyed by Paisley and Atkin [10]. Paisley and Atkin argued that to create behavior change, the efforts made must be an integration of three aspects called the three Es, namely, education, engineering, and enforcement [11].

In the context of COVID-19, the public has long been given education about the importance of wearing masks, maintaining distance, and using disinfectants. Campaigns by various institutions have been massively developed so far, using various types of social media, television, newspapers and magazines, as well as public media. The message is clear, that COVID-19 can be prevented by following the health protocols recommended by the government. Meanwhile, engineering is present by ensuring that the contents of the message can be easily implemented through the presence of affordable masks, disinfectants whose products are available in the market, and hand washing facilities in all public areas. Those two things, education and engineering, have been going on since the pandemic occurred.

However, these two things cannot be effective without enforcement. Enforcement is needed to ensure that people change their behavior according to the message and engineering that has been designed for it. In the field of public health, two popular things to make enforcement an important principle are the use of seat belts and control of cigarette consumption. In an effort to reduce traffic accidents, the application of fines to motorists has actually increased seat belt compliance. Likewise, regulations that tighten penalties on cigarette sellers and users have made tobacco control successful. In the long term, the enforcement of these two things can prevent health problems from increasing, including the rate of traffic accidents and lung cancer patients. 
That is what is currently being carried out in many countries that are able to control COVID- 19 cases. They ensure community compliance with established health protocols [12], [13]. The decline in infection rates occurred in India, including in Spain, Germany, Italy, the UK, and France, Belgium, Austria, New Zealand, India, Hungary, Poland, and Malaysia, even China and the US, when enforcement was implemented [7], [14], [15], [16], [17]. An effective strategy does need to be developed according to the context of each country [18], but with strict controls, regarding movement restrictions [19], [20] to ensure social distancing, including the implementation of school closures, crowd restrictions, and cessation of public services, which is done either in full or in part [21], [22], [23]. The experience of tight pandemic control since COVID-19 erupted in China provides a clear signal that disciplined enforcement is an important keyword [24]. The compliance even concerns crossborder restrictions to prevent imported cases [25].

Relaxing activities and even compliance can indeed be done, but require modifications that adapt to the conditions of society because COVID-19 has economic consequences [22]. The relaxation of activities takes into account the circulation of patients, daily cases, and other important trends originating from hospitals and treatment facilities. Hence, the enforcement of the rules should be done not when the case is high, but when the trend is sloping. Delay in responding to these conditions will result in delays in controlling the situation [26]. This means that discipline is strictly enforced before the COVID-19 case reaches its peak. Unfortunately, in the 6 months before the peak of this pandemic occurred, enforcement in Indonesia did not appear to be well enforced.

This is the key point that causes Indonesia to become the epicenter of COVID-19 in the early second half of 2021. Like an epidemic, this will certainly end, when the curve reaches its peak. However, this condition will certainly happen again, if enforcement, as an important policy [27], is not seriously implemented by all elements of society and local governments.

\section{Future Planning}

Even though the resulting social consequences are so great [28], COVID-19 disease can be controlled [29]. The WHO itself admits that countries with excellent readiness and alertness in responding to COVID-19 are now being overwhelmed by the Delta variant. Many countries that initially managed to control COVID-19 are now preparing to face the eruption of a new variant of the virus. Daily cases in many countries have increased, after the easing of the restrictions that have been carried out so far even though the pandemic is not over [30]. This means that health discipline enforcement policies will greatly determine the condition of COVID-19 in a country [31], [32], [33].

Indonesia must learn from the current situation. At first glance, it is easy to see if people's behavior seems not to be good. Here and there, the practice of health protocols (prokes) is still very loose. The use of masks, the habit of washing hands, and maintaining distance are still very lacking, even when it continues to this emergency PPKM period. People's refusal to comply with enforcement during emergency PPKM is the result of neglect of discipline so far. Revitalization of discipline is needed as an ecosystem of positive behavior on a wide scale [34], [35], [36], [37], [38], [39] through the application of a combination of three Es. If it is successfully created, Indonesia will lead to the realization of the social discipline that is very much needed to fight the spread of COVID-19 consistently even though it remains dynamic. The essence of controlling COVID-19 lies in the discipline of policies to control the mobility of the population's behavior. If this is effectively implemented, the daily number of COVID-19 sufferers can be reduced, although it is not to eliminate COVID-19 itself.

\section{Conclusion}

We hope that the government will be firm in applying discipline to health protocols. The implementation of the tightening policy may be more emphasized without sacrificing the people's economy, as has always been stated by the government so far.

\section{References}

1. World Health Organization. WHO Coronavirus Disease (COVID- 19) Dashboard. Geneva: World Health Organization; 2021. Available from: https://www.covid19.who.int [Last accessed on $2021 \mathrm{Jul} 18]$.

2. Satuan Tugas Penanganan COVID-19, "Peta Sebaran," 2021; 2021. Available from: https://www.covid19.go.id/peta-sebaran [Last accessed on $2021 \mathrm{Jul} 18]$

3. Worldometer, COVID-19 Coronavirus Pandemic; 2021 Available from: https://www.worldometers.info/coronavirus [Last accessed on $2021 \mathrm{Jul} 18]$

4. World Health Organization. COVID-19 Weekly Epidemiological $48^{\text {th }}$ ed. Geneva: World Health Organization; 2021. Available from: https://www.who.int/publications/m/item/weeklyepidemiological-update-on-covid-19 [Last accessed on 2021 Jul 13].

5. Ministry of Health, Vaksinasi COVID-19 Nasional; 2021 Available from: https://www.vaksin.kemkes.go.id/\#/vaccines [Last accessed on $2021 \mathrm{Jul} 18$ ].

6. Parino F, Zino L, Porfiri M, Rizzo A. Modelling and predicting the 
effect of social distancing and travel restrictions on COVID-19 spreading. J R Soc Interface. 2021;18(175):20200875. https:// doi.org/10.1098/rsif.2020.087

\section{PMid:33561374}

7. Verma BK, Verma M, Verma VK, Abdullah RB, Nath DC Khan HT, et al. Global lockdown: An effective safeguard in responding to the threat of COVID-19. J Eval Clin Pract. 2020;26(6):1592-8. https://doi.org/10.1111/jep.13483 PMid:32970386

8. DiClemente R, Salazar L, Crosby R. Health Behavior Theory for Public Health Principles, Foundations, and Applications. $2^{\text {nd }}$ ed. Burlington, MA: Jones \& Bartlett Learning; 2019.

9. Scriven A. Promoting Health A Practical Guide. $6^{\text {th }}$ ed. Tamil Nadu: Elsevier Ltd.; 2010.

10. Paisley W, Atkin CK. Public communication campaigns-the american experience. In: Rice RE, Atkin CK, editors. Public Communication Campaigns. $4^{\text {th }}$ ed. New York, United States: SAGE; 2013

11. Storey JD, Saffitz GB, Rimón JG. Social marketing. In: Glanz K, Rimer BK, Viswanath K, editors. Health Behavior and Health Education: Theory, Research, and Practice. $4^{\text {th }}$ ed. San Francisco, CA: Jossey-Bass; 2008.

12. MGallaway MS, Rigler J, Robinson S, Herrick K, Livar E, Komatsu KK, et al. Trends in COVID-19 incidence after implementation of mitigation measures-arizona, January 22-August 7, 2020. MMWR Morb Mortal Wkly Rep. 2020;69(40):1460-3. https://doi.org/10.15585/mmwr. $\mathrm{mm} 6940 \mathrm{e} 3$

PMid:33031366

13. Al Zobbi M, Alsinglawi B, Mubin O, Alnajjar F. Measurement method for evaluating the lockdown policies during the COVID- 19 pandemic. Int $\mathrm{J}$ Environ Res Public Health. 2020;17(15):5574. https://doi.org/10.3390/ijerph17155574 PMid:32748822

14. Ghosal S, Bhattacharyya R, Majumder M. Impact of complete lockdown on total infection and death rates: A hierarchical cluster analysis. Diabetes Metab Syndr. 2020;14(4):707-11. https://doi.org/10.1016/j.dsx.2020.05.026

PMid:32426062

15. Peng Z, Song W, Ding Z, Guan Q, Yang X, Xu Q, et al. Linking key intervention timings to rapid declining effective reproduction number to quantify lessons against COVID-19. Front Med. 2020;14(5):623-9. https://doi.org/10.1007/s11684-020-0788-3 PMid:32495288

16. Dhami MK, Weiss-Cohen L, Ayton P. Are people experiencing the 'pains of imprisonment' during the COVID-19 lockdown? Front Psychol. 2020;11:578430. https://doi.org/10.3389/ fpsyg.2020.578430

PMid:33329229

17. Delen D, Eryarsoy E, Davazdahemami B. No place like home: Cross-national data analysis of the efficacy of social distancing during the COVID-19 pandemic. JMIR Public Health Surveill. 2020;6(2):e19862. https://doi.org/10.2196/19862 PMid:32434145

18. Hasan HF. Legal and health response to COVID-19 in the arab countries. Risk Manag Healthc Policy. 2021;14:1141-54. https:// doi.org/10.2147/RMHP.S297565 PMid:33758566

19. Badr HS, Du H, Marshall M, Dong E, Squire MM, Gardner LM. Association between mobility patterns and COVID-19 transmission in the USA: A mathematical modelling study. Lancet Infect Dis. 2020;20(11):1247-54. https://doi.org/10.1016/ S1473-3099(20)30553-3

PMid:32621869

20. Casares $\mathrm{M}, \mathrm{Khan} \mathrm{H}$. The timing and intensity of social distancing to flatten the COVID-19 curve: The case of spain. Int J Environ Res Public Health. 2020;17(19):7283. https://doi.org/10.3390/ ijerph17197283

PMid:33036132

21. Lewtak $K$, Nitsch-Osuch $A$. What is the effect of social distancing on the course of COVID-19 epidemic? Pol Merkur Lekarski. 2021;49(289):71-9.

PMid:33713099

22. Gargoum SA, Gargoum AS. Limiting mobility during COVID-19, when and to what level? An international comparative study using change point analysis. J Transp Health. 2021;20:101019. https://doi.org/10.1016/j.jth.2021.101019

PMid:33777694

23. Bante A, Mersha A, Tesfaye A, Tsegaye B, Shibiru S, Ayele G, et al. Adherence with COVID-19 preventive measures and associated factors among residents of dirashe district, Southern Ethiopia. Patient Prefer Adherence. 2021;15:237-249. https:// doi.org/10.2147/PPA.S293647

PMid:33568900

24. Peng F, Tu L, Yang Y, Hu P, Wang R, Hu Q, et al. Management and treatment of COVID-19: The Chinese experience. Can J Cardiol. 2020;36(6):915-30. https://doi.org/10.1016/j. cjca.2020.04.010

PMid:32439306

25. Bielecki M, Patel D, Hinkelbein J, Komorowski M, Kester J, Ebrahim S, et al. Air travel and COVID-19 prevention in the pandemic and peri-pandemic period: A narrative review. Travel Med Infect Dis. 2021;39:101915. https://doi.org/10.1016/j. tmaid.2020.101915

PMid:33186687

26. Loewenthal G, Abadi S, Avram O, Halabi K, Ecker N, Nagar N, et al. COVID-19 pandemic-related lockdown: Response time is more important than its strictness. EMBO Mol Med. 2020;12(11):e13171. https://doi.org/10.15252/ emmm.202013171

PMid:33073919

27. Wilder-Smith A, Chiew CJ, Lee VJ. Can we contain the COVID-19 outbreak with the same measures as for SARS? Lancet Infect Dis. 2020;20(5):e102-7. https://doi.org/10.1016/ S1473-3099(20)30129-8

PMid:32145768

28. Sarumpaet S, Zaluchu F, Eyanoer PC, Simanjuntak NH. Fighting against COVID-19 and fighting against stigma: A mini- review. Open Access Maced J Med Sci. 2020;8(T1):522-5

29. Salvamani S, Tan HZ, Thang WJ, Ter HC, Wan MS, Gunasekaran B, et al. Understanding the dynamics of COVID-19; implications for therapeutic intervention, vaccine development and movement control. Br J Biomed Sci. 2020;77(4):168-84. https://doi.org/10.1080/09674845.2020.1826136 PMid:32942955

30. World Health Organization. WHO Director-General's Opening Remarks at the $8^{\text {th }}$ Meeting of the IHR Emergency Committee on COVID-19. Geneva: World Health Organization; 2021. Available from: https://www.who.int/director-general/speeches/detail/ who-director-general-s-opening-remarks-at-the-8th-meeting-ofthe-ihr-emergency-committee-on-covid-19-14-july-2021 [Last accessed on 2021 Jul 19].

31. Aravindakshan A, Boehnke J, Gholami E, Nayak A. Preparing for a future COVID-19 wave: Insights and limitations from a data-driven evaluation of non-pharmaceutical interventions in Germany. Sci Rep. 2020;10(1):20084. https://doi.org/10.1038/ s41598-020-76244-6 PMid:33208764

32. Al-Hasan A, Yim D, Khuntia J. Citizens' adherence to COVID- 19 mitigation recommendations by the government: A 3-country 
comparative evaluation using web-based cross-sectional survey data. J Med Internet Res. 2020;22(8):e20634. https:// doi.org/10.2196/20634

PMid:32716896

33. Lee $D$, Heo K, Seo $Y$, Ahn H, Jung K, Lee S, Choi $H$. Flattening the curve on COVID-19: South Korea's measures in tackling initial outbreak of Coronavirus. Am J Epidemiol. 2021;190(4):496- 505. https://doi.org/10.1093/aje/kwaa217 PMid:33106843

34. Gupta MK, Bhardwaj P, Goel A, Saurabh S, Misra S. COVID-19 appropriate behavior in India: Time to invest for the benefits in future. J Family Med Prim Care. 2021;10(5):1818-22. https://doi. org/10.4103/jfmpc.jfmpc_2382_20

PMid:34195109

35. Nix J, Ivanov S, Pickett JT. What does the public want police to do during pandemics? A national experiment. Criminol Public Policy. 2021. https://doi.org/10.1111/1745-9133.12535 PMid:33821153

36. Pataro IM, Oliveira JF, Morato MM, Amad AA, Ramos PI,
Pereira FA, et al. A control framework to optimize public health policies in the course of the COVID-19 pandemic. Sci Rep. 2021;11(1):13403. https://doi.org/10.1038/ s41598-021-92636-8

PMid:34183727

37. Roth Y, Plonsky O, Shalev E, Erev I. On the value of alert systems and gentle rule enforcement in addressing pandemics. Front Psychol. 2020;11:577743. https://doi.org/10.3389/ fpsyg.2020.577743 PMid:33329225

38. Tang KHD. Movement control as an effective measure against COVID- 19 spread in Malaysia: An overview. Z Gesundh Wiss. 2020:1-4. https://doi.org/10.1007/s10389-020-01316-w PMid:32837842

39. Zabuha YY, Mykhailichenko TO, Rak SV. Legal regulation of epidemic security under the COVID-19 pandemic conditions in some post-soviet countries and Poland. Wiad Lek. 2020;73(12 Cz 2):2758-67.

PMid:33611278 